\title{
THE LONG-TERM EFFECTS OF REPEATED AMPHETAMINE TREATMENT IN VIVO ON AMPHETAMINE, KCI AND ELECTRICAL STIMULATION EVOKED STRIATAL DOPAMINE RELEASE IN VITRO
}

\author{
Edward Castañeda ${ }^{1}$, Jill B. Becker ${ }^{1,2}$ and Terry E. Robinson $1,2,3$
}

\author{
Department of Psychology ${ }^{1}$ and Neuroscience Program ${ }^{2}$ \\ The University of Michigan, Neuroscience Laboratory Bldg. \\ 1103 East Huron Street, Ann Arbor, MI 48109
}

(Recelved in final form April 12, 1988)

\begin{abstract}
Summary
Exposure to amphetamine (AMPH) in vivo produces an enduring enhancement ('sensitization') in AMPH-stumulated stratal DA release in vitro. Experiments were conducted to determine whether striatal DA release evoked by neuronal depolarization is altered by AMPH pretreatment in a similar manner. It was found that AMPH pretreatment produced a long-lasting (at least one week) enhancement in striatal DA release evoked by AMPH, $\mathrm{KCl}$ or electrical field stimulation. In contrast, the basal rate of DA efflux was not altered by pretreatment condition. A mechanism by which a single change in the intracellular distribution of DA could enhance both AMPH- and depolarization-induced DA release is proposed.
\end{abstract}

In humans chronic amphetamine (AMPH) abuse frequently results in the development of a drug-induced psychosis (AMPH psychosis) that is clinically simular to paranoid schizophrenıa (1-4). In nonhuman animals repeated treatment with AMPH produces a progressive enhancement in the motor stimulant effects of AMPH (behavioral sensitization), and this phenomenon ss considered an animal analogue of AMPH psychosis $(5,6)$. There has been considerable interest, therefore, in the neurobiological basis of behavioral sensitization. Research on this question has focused on mesotelencephalic dopamine (DA) systems, in part because AMPH is thought to produce many of its effects on behavior by enhancing dopaminergic actuvity, especrally DA release (7-9).

Many neural correlates of behavioral sensitization have been reported in the literature (5), and of particular relevance here are reports that behavioral sensitization is accompanied by an enhancement in AMPH-stımulated striatal DA release in vitro (10-12) This change in AMPHstumulated DA release can account for a number of features of the behavioral phenomenon. For example, both behavioral sensitization and an increase in AMPH-stimulated striatal DA release in vitro: (a) can be produced by a single injection of AMPH (12, cf.13); (b) persist for a very long time following the cessation of drug treatment $(10,11)$; and (c) are similarly influenced by how long animals are withdrawn from AMPH pretreatment (10). It has been suggested, therefore, that an enduring change in the releasability of DA may be responsible for some of the enduring changes in behavior produced by past expenence with $\operatorname{AMPH}(5,11)$.

To narrow down the mechanism(s) by which pnor AMPH treatment enhances striatal DA release it is important to determine if the effect is specific to AMPH-stimulated DA release, or whether the DA

3 To whom correspondence and reprint requests should be addressed

$$
\begin{aligned}
& \text { 0024-3205/88 } \$ 3.00+.00 \\
& \text { Copyright (c) } 1988 \text { Pergamon Press plc }
\end{aligned}
$$


release produced by neuronal depolanzation is changed in a similar manner This is because DA release stımulated by AMPH is due to a different process than the neurotransmitter release associated with impulse flow and the depolarization of axonal terminals (9) Depolarization-induced DA release is thought to occur by $\mathrm{Ca}++$-dependent exocytosis, whereas AMPH-stumulated DA release is thought to occur by a $\mathrm{Ca}^{++}$-1ndependent exchange-diffusion process involving the DA reuptake carrier $(9$, 14) To address this question experiments were conducted using an in vitro superfusion technique to determine the effects of AMPH pretreatment on endogenous stratal DA release elicited by either (a) AMPH, (b) $\mathrm{KCl}$ depolanzation; or (c) depolarization by electncal field stımulation.

\section{Methods}

\section{Subjects and Surgıcal Preparanon}

Adult female Holtzman rats (Holtzman Co., Madison, WI) were housed individually with food and water freely avaulable. The colony room was temperature regulated and lights were maintained on a 14:10 hr light.dark cycle (lights on at $08: 00 \mathrm{hr}$ ). Seven to 14 days before the start of an experiment animals were ovanectomized under ether anesthesia Ovanectomized female rats were used for the following reasons: (a) female rats show more robust behavioral sensitization than do males $(15,16)$; and (b) ovariectomy eliminates the variation in stratal DA release associated with hormonal fluctuations across the estrous cycle (17), but has no effect on sensitzation $(16,18)$

\section{Quantification of Behavior}

After each pretreatment injection of AMPH or saline anımals were immediately replaced into their home cage and behavior quantified by direct visual observation and rating of stereotyped behavior. Animals were rated during a $1 \mathrm{~min}$ observation period every $20 \mathrm{~min}$ following the injection, for a total of $3 \mathrm{hr}$. Overall stereotyped behavior was rated with a scale adapted from MacLennan and Maier (19). Individual components of stereotyped behavior (1 e., smiffing, repettive head and limb movements and oral behaviors) were rated as described by Rebec and Segal (20). A darly cumulative score for each ratung scale was calculated by summing the ratings obtained during each test session. In addition, the total volume of water ingested over $5 \mathrm{hr}$ following each injection was recorded.

\section{In Vitro DA Release}

One week after the last pretreatment with AMPH each rat was kulled by decapitation, and the brain was quickly removed and placed into ice-cold medium Coronal sections were obtained using a cutting block similar to that described by Heffner, Hartman and Seiden (21), and after each striatum was chopped into $1 \mathrm{~mm}^{3}$ pieces it was placed into a superfusion chamber. The superfusion chambers and methods have been described previously (22). Briefly, the superfusion medium consisted of a modified Krebs-Ringer phosphate buffer with a final composition of: $120 \mathrm{mM} \mathrm{NaCl}$, $4.8 \mathrm{mM} \mathrm{KCl}, 1.25 \mathrm{mM} \mathrm{CaCl} 2 \cdot 2 \mathrm{H}_{2} 0,15 \mathrm{mM} \mathrm{MgSO} 4,15 \mathrm{mM}$ phosphonc acid, $0.1 \%$ bovine serum albumin, $10 \mathrm{mM}$ glucose and $\mathrm{pH} 7.4$ The medium was oxygenated with $95 \% \mathrm{O}_{2} \cdot 5 \% \mathrm{CO}_{2}$ for $15 \mathrm{~min}$ and sturred continuously throughout the experiment Superfusion chambers were maintained at $34^{\circ} \mathrm{C}$, and medium was pumped through the chambers at $100 \mu \mathrm{l} / \mathrm{min}$ After tissue was placed into a superfusion chamber it was left to equllibrate for $65 \mathrm{~min}$ before beginning sample collection. Samples were then collected over 5-min intervals in 1ce-chilled tubes containing $25 \mu \mathrm{l}$ of $0.5 \mathrm{~N} \mathrm{HClO}_{4}$ with dihydroxybenzylamine added as an internal standard. Samples were stored at $-20^{\circ} \mathrm{C}$ untal assayed by high performance liquid chromatography with electrochemical detection, as described previously (22)

The data from each superfusion were examined by an expenenced judge (J B.B.) who was blind to the treatment conditions, and chambers that failed to meet the following critera were not considered viable and were excluded from the experiment For a chamber to be considered viable (a) stumulated DA release had to be greater than basal DA efflux (1.e., there was not a progressive decrement in DA efflux); and (b) at the end of the experiment the tissue had to respond to a $60 \mathrm{mM}$ $\mathrm{KCl}$ challenge by an increase in DA release (indicating that the tussue was still viable) Chambers 
were usually excluded for reasons directly attributable to experimenter error or equipment malfunction, and there was no group bias in the number of chambers excluded. These methods were used in all of the following experiments, and procedures specific to each experiment are described below.

\section{Experiment 1: The effect of AMPH pretreatment on AMPH-stimulated striatal DA release in vitro: dose-response relotions}

Amphetamine pretreatment Animals were either pretreated with $3.0 \mathrm{mg} / \mathrm{kg}$ of $d$-AMPH sulfate (1.p.) dissolved in $0.9 \%$ saline (weight of the salt) once dally for 6 consecutive days, or left undisturbed in their home cage (non-handled). Non-handled controls were used in this experiment to minımize the stress-induced sensitization of dopamınergic activity sometimes produced by repeated saline injections $(23,24)$.

Superfusion After the $65 \mathrm{~min}$ equllibration period (see above) 3 baseline samples were collected over $15 \mathrm{~min}$. At the beginning of the next interval medium containing $d$-AMPH was infused for either $5 \mathrm{~min}$ (with $0.5,2.75$ and $5.0 \mu \mathrm{M}$ AMPH), or $2.5 \mathrm{~min}$ (with $10 \mu \mathrm{M} \mathrm{AMPH}$ ), and samples collected for an additional $30 \mathrm{~min}$ (all independent groups). Finally, $60 \mathrm{mM} \mathrm{KCl}$ was infused for $25 \mathrm{~min}$ and one additional 5-min sample was collected. It should be noted that the doses of AMPH used here are just at threshold for evoking consistent DA release in this apparatus, representung the extreme far left and nonlinear portaon of the dose-response curve for AMPH-evoked striatal DA release (see Fig. 4 in ref. 22). It was hoped that this would maximize the probability of detectung an increase in the releasabulity of DA due to pretreatment condition.

\section{Experiment 2: The effect of AMPH pretreatment on $\mathrm{KCl}$-evoked DA release}

Amphetamine pretreatment. Anumals received $30 \mathrm{mg} / \mathrm{kg}$ of $d$-AMPH or $1.0 \mathrm{ml} / \mathrm{kg}$ of $0.9 \%$ salune once a week for 5 weeks (a total of 5 injections).

Superfusion One week after the last injection of AMPH or saline stnatal tissue was placed into superfusion chambers as described above, except after baseline the tussue was stimulated by including 25,35 or $45 \mathrm{mM} \mathrm{KCl}$ in the medium for $5 \mathrm{~min}$ (the concentration of $\mathrm{NaCl}$ was reduced proportionately). The DA release evoked by these concentrations of $\mathrm{KCl}$ has been previously shown to be $\mathrm{Ca}^{+}+$and temperature-dependent (22).

\section{Electrical stimulation-Induced DA release}

Apparatus The top and bottom of each superfusion chamber was fitted with a $\mathrm{Ag}-\mathrm{AgCl}$ electrode (In Vivo Metric Systems, Healdsburg, CA). The circular surface of the top electrode had a cross-sectional diameter of $15 \mathrm{~mm}$ and the bottom electrode a diameter of $40 \mathrm{~mm}$. The electrodes were soldered with $\mathrm{Ag}$ solder to lead wires and the solder joint reinforced with a conductive $\mathrm{Ag}$ epoxy adhesive (Tra-Con). The electrodes were insulated with teflon heat-shrink tubing, except for the cross-sectional area of the tp, and were separated by $12 \mathrm{~mm}$ (which maintained a $200 \mu \mathrm{l}$ volume in the chambers) Nylon mesh spacers were used to prevent tissue from restung directly on the electrode surface

$\mathrm{Ag}-\mathrm{AgCl}$ electrodes were used rather than platinum, which is frequently used for in vitro stumulaton expenments, for several reasons: (a) It has been reported that platunum acts as a catalyst for the oxıdation of neurotransmitter substrates or of glucose, but $\mathrm{Ag}$ has minımal deletenous effects on tissue viability compared to other metals (25-27), (b) Ag apparently does not affect tissue metabolism (25), and (c) chlonded electrodes are maximally inert to physiological solutions and resistant to electrolytic processes $(25,27)$

The electrical stımulus was provided by a Grass S8 stumulator and consisted of two rectangular D.C pulses that were passed through individual sumulus isolation units (Grass Model SIU 478A) and individual constant current units (Grass Model CCU1A). The second pulse was delayed by the duration of the first pulse and its polarity reversed at the constant current unit to create a true biphasic pulse. Biphasic pulses were used to minimize the tissue damage and electrode polarzation 
sometimes associated with the use of monophasic pulses in vitro (28). Current was monitored by recording the voltage drop across a resistor located in series with the chamber.

Pilot studies. A series of pulot expenments were conducted to valddate the electrical stimulation procedures and to determine suitable stumulus parameters. First, the intensity, pulse duration and pulse frequency were varied to determine parameters that evoked a consistent enhancement in DA release. Second, the effect of varyung the sumulus frequency $(5,10,20,30$, 40, or $50 \mathrm{pulse} / \mathrm{sec}$, [pps]) on DA release was determuned, while current $(40 \mathrm{~mA})$ and pulse duration $(2 \mathrm{msec})$ were held constant.

The third issue addressed in pilot studies was whether the release produced by a highly effective stumulus was sensitive to calcium and temperature. With electrical stumulation it is possible to produce nonselective neurotransmitter release with high intensity stimulation (29) It is difficult, however, to compare stimulation parameters from lab-to-lab because resistance varies greatly with such things as chamber volume, the density of tissue packing, and the surface area and distance between the electrodes. As pointed out by Orrego (28, p 1048) it is not possible to know the actual stumulating current because, "most of the current that flows in the system is short circuited through the bulk of the liquid" Therefore, superfusion experiments were conducted as described above, except chambers were tested with either: (a) normal medium at $34^{\circ} \mathrm{C}$, (b) medium without additional $\mathrm{Ca}^{++}$(magnesium was increased to $2.45 \mathrm{mM}$ ) and at $34^{\circ} \mathrm{C}$, or (c) normal medium, but at $0^{\circ} \mathrm{C}$ Stimulus parameters that produced a rate of DA release of approxımately $200 \mathrm{pg} \mathrm{DA} / \mathrm{mg}$ tssue/min were used, which consisted of $40 \mathrm{~mA}, 2 \mathrm{msec}$ pulses apphed at $50 \mathrm{pps}$ for a total of $2 \mathrm{~min}$.

\section{Experiment 3: The effect of AMPH pretreatment on electrical stimulation-evoked DA release}

Amphetamine pretreatment. Anumals recelved etther an $1 \mathrm{p}$ injection of $3.0 \mathrm{mg} / \mathrm{kg}$ of $d$-AMPH sulfate or $1 \mathrm{ml} / \mathrm{kg}$ of $09 \%$ salıne once a day for 6 consecutive days An additional group was left undisturbed in their home cages during this time (nonhandled). Behavior was monitored only followng the first and sixth injection, as described above

Superfusion One week after the last injection superfusion expenments were conducted as previously descnbed, except 20 -min fractions were collected for a total of 3 samples After one baseline sample was collected the tissue was stimulated with electncal field stımulation consisting of biphasic rectangular pulses ( $20 \mathrm{~mA}, 2 \mathrm{msec}$ duration) applied for $10 \mathrm{sec}$ on/10 sec off for $40 \mathrm{~mm}$ Independent groups of chambers were stumulated at either 5,10 , or $20 \mathrm{pps}$ It should be noted that the highest rate of stimulation used in this experiment ( $20 \mathrm{pps})$ was ten tumes lower than used in the pilot experiment to determine $\mathrm{Ca}^{++}$and temperature dependence $(08 \mathrm{mCoulombs} / \mathrm{sec} v \mathrm{~s}$ $8 \mathrm{mCoulombs} / \mathrm{sec}$, respectively), and that each chamber was tested with only one frequency.

\section{Results}

\section{Behovior.}

All of the AMPH pretreatment regamens produced a sumlar and significant enhancement in the motor stımulant effects of AMPH (1 e , behavioral sensitization) Data are shown only for Exp. 2 to lllustrate typical behavioral effects (also see 15, 18,30). Fig 1 shows that repeated AMPH treatment produced a progressive and significant enhancement in the ratings of overall stereotypy, sniffing and repetutuve head movements, and in the amount of water ingested There was no effect of repeated AMPH treatment on oral stereotypies (data not shown), consistent with previous reports $(20,31)$

\section{Experiment 1: The effect of AMPH pretreatment on AMPH-stımulated striatal DA release in vitro.}

Fig 2 shows that the inclusion of AMPH in the superfusion medium enhanced endogenous striatal DA release above basal levels of DA efflux in all groups (1 e, all means are significantly greater than 0). There was no effect of AMPH pretreatment on AMPH-stımulated DA release evoked by infusion of $05 \mu \mathrm{M}$ or $275 \mu \mathrm{M}$ AMPH for $5 \mathrm{~mm}$ However, infusion of $5 \mu \mathrm{M}$ AMPH 
for $5 \mathrm{~min}$, or $10 \mu \mathrm{M}$ for $2.5 \mathrm{~mm}$, produced a significantly greater increase in DA release in the AMPH pretreated group than in the control group (Fig. 2).
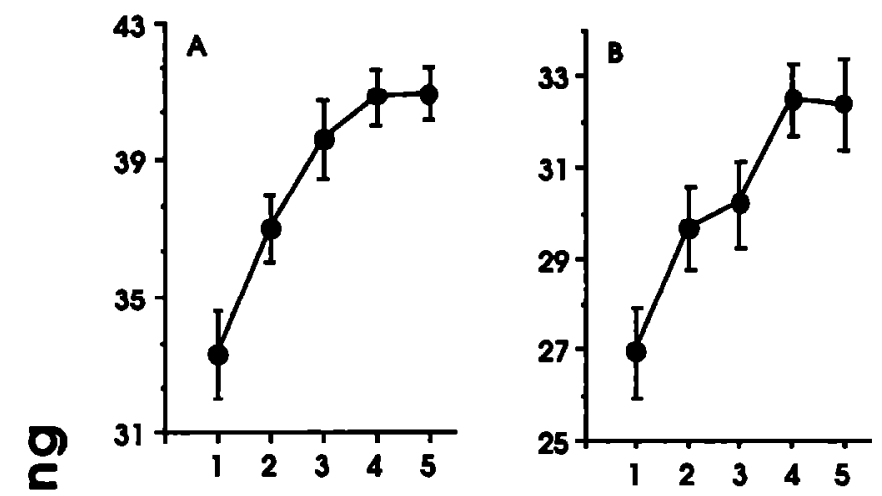

Eig. 1. The effect of repeated AMPH treatment on stereotypy ratings and drinking behavior. The symbols represent the mean $( \pm S . E . M ; N=38)$ values after each of 5 injections of $30 \mathrm{mg} / \mathrm{kg}$ of $\mathrm{AMPH}$ given at weekly intervals There was a significant increase in the ratings of overall stereotypy (A), sniffing $(B)$, and head and limb
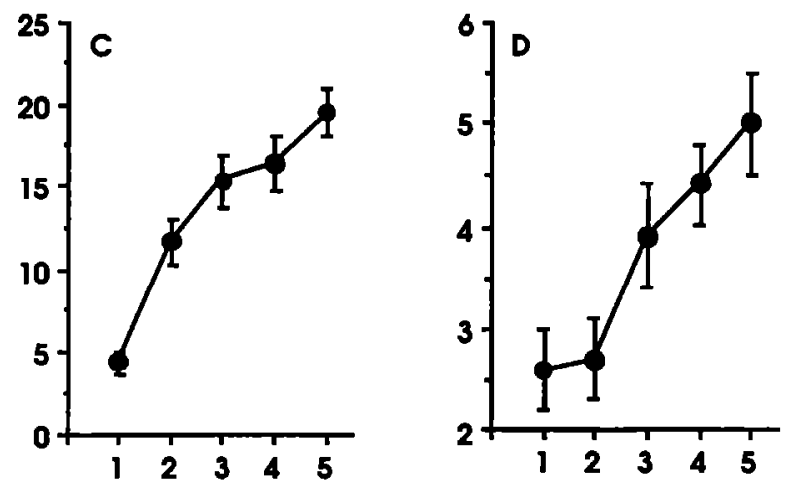
movments $(C$; comparison of first and last injection, Wilcoxon tests, p's < $0001)$ The increase in water consumption $(\mathrm{ml})$ was also significant $(D$, paired $t$-test, $p<0$ 001)

\section{Injection Number}

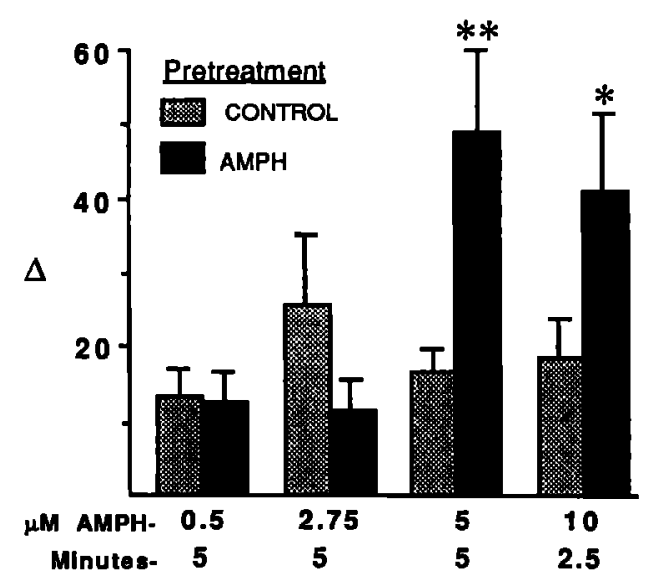

Eig. 2. The effect of pretreatment with AMPH on AMPH-stimulated endogenous striatal DA release in vitro. The bars represent the mean (+S.E.M.) change ( $\Delta$ ) in DA efflux from baseline, expressed in pg DA/mg tissuelmin (i e., a value of zero represents no change from baseline) The groups did not differ in the basal rate of DA efflux, which averaged $23.97 \pm 0.97$ $\mathrm{pg} / \mathrm{mg} / \mathrm{min}$ across all groups. There was no effect of pretreatment condition on DA release evoked by elther 05 or $2.75 \mu M$ AMPH. However, there was a greater increase in $D A$ efflux from the AMPH-pretreated group when the tissue was challenged with $5 \mu M$ of $A M P H$ for 5 min or $10 \mu \mathrm{M}$ for 25 min (planned 1-talled $t$-tests, $t[8]=315,{ }^{* *} p=0007, t[7]=2.22$, ${ }^{*} p=0$ 031, respectively) 


\section{Experiment 2: The effect of AMPH pretreatment on KCl-evoked strlatal DA release.}

Fig. 3 shows that the addition of 25 to $45 \mathrm{mM} \mathrm{KCl}$ to the superfusion medium increased endogenous DA release above the basal level of DA efflux in all groups (1.e., all means are greater than 0 ). More importantly, $\mathrm{KCl}$ produced a greater increase in DA release in the AMPH-pretreated group than in the control group. The 2-way analysis of variance resulted in a significant main effect and no significant interaction, but inspection of Fig. 3 reveals a tendency for a larger effect of pretreatment condition with the higher concentrations of $\mathrm{KCl}$

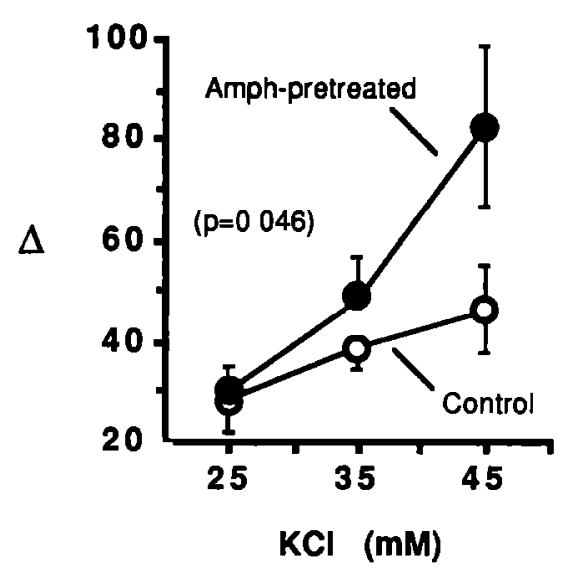

\begin{abstract}
Eig. 3 The effect of pretreatment with AMPH (solid circles) on endogenous striatal DA release evoked by 25,35 or $45 \mathrm{mM} \mathrm{KCl}$ in vitro The symbols represent the mean ( $\pm S E M$ ) change ( $\Delta$ ) in DA efflux from baseline, expressed in $p g$ DAlmg tussue/min. There were no group differences in the basal rate of DA efflux, which averaged $1822 \pm 171 \mathrm{pg} / \mathrm{mg} / \mathrm{min}$ across all groups However, a 2-way analysis of variance on the change in DA efflux produced by $\mathrm{KCl}$ resulted in a stgnificant effect of pretreatment condition $(F[1,32]=417, p=0046), a$ significant effect of $K C l$ concentratton $(F[2,32]$ $=699, p=0003)$ but no significant interaction
\end{abstract}

\section{Electrical stimulation-induced DA release: Pilot experiments.}

A $40 \mathrm{~mA}, 2 \mathrm{msec}$ stumulus appled for $2 \mathrm{~min}$ did not produce a significant increase in DA efflux at frequencies below 20 pps. As the stumulus frequency was increased above 20 pps DA efflux increased to an average of approximately $200 \mathrm{pg} \mathrm{DA} / \mathrm{mg}$ tssue/min at $50 \mathrm{pps}$. The increase in DA efflux produced by the highest intensity stimulus tested ( $40 \mathrm{~mA}, 2 \mathrm{msec}, 50 \mathrm{pps}$ ) was reduced by $74 \%$ if $\mathrm{Ca}^{++}$was excluded from the medium, and this stamulus was completely ineffective in inducing DA release when the chambers were kept at $0^{\circ} \mathrm{C}$

\section{Experiment 3: The effect of AMPH pretreatment on electrlcal stimulation-evoked DA release.}

Electrical stumulation significantly enhanced DA release above the basal levels of DA efflux in all groups (1 e., all means are greater than 0; Fig 4) There was no difference between the salinepretreated and nonhandled control groups, and therefore they were pooled for companson with the AMPH-pretreated group. Electrical sumulation evoked a greater change in DA release in the AMPHpretreated group than in the control group, as indicated by a significant main effect of pretrearment condition (2-way ANOVA) The ANOVA did not result in a significant interaction, but inspection of Fig. 4 reveals a tendency for a greater effect at the highest stimulus frequency

\section{Discussion}

The AMPH pretreatment regimens used in the present expenments produced behavioral sensituzation, as expected from previous studies $(30,32-34,5$ for review). Furthermore, behavioral sensitization was accompanied by a dose-related enhancement in AMPH-stimulated striatal DA release in vitro, which confirms and extends previous studies (10-12). Most importantly, AMPH pretreatment also produced an endurning enhancement in the $\mathrm{Ca}^{++}$-dependent release of DA evoked by high $\mathrm{KCl}$ or electrical field stumulation. These latter studies establish that sensitization-related changes in stratal DA release are not unique to AMPH-stumulated DA release 


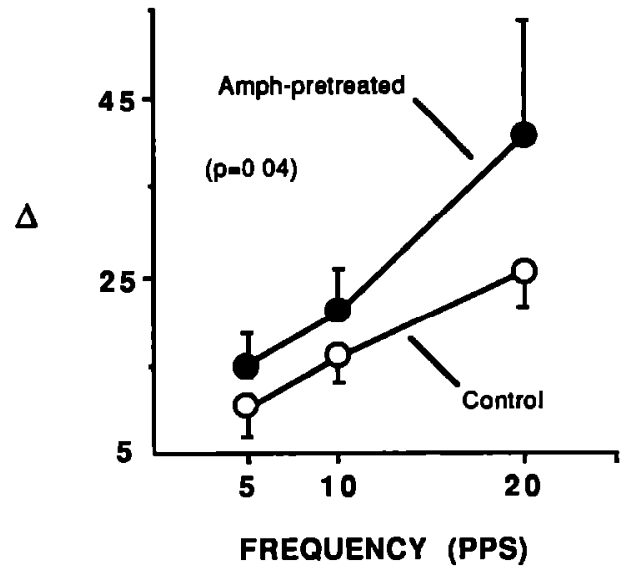

Eis. 4. The effect of pretreatment with AMPH (solid symbols) on endogenous striatal DA release in vitro evoked by electrical field stimulation applied at 5, 10 or 20 pulses/sec (PPS). The symbols represent the mean (土S.E.M.) change ( $\Delta)$ in DA efflux from baseline, expressed in $p g$ DAlmg tissuelmin. There were no group differences in the basal rate of DA efflux, which averaged $16.53 \pm 1.06 \mathrm{pg} / \mathrm{mg} / \mathrm{min}$ across all groups. However, a 2-way analysis of variance on the change in DA efflux produced by electrical stimulation resulted in a significant effect of pretreatment condition $(F[1,82]=4.24, p=$ $0.04)$, a significant effect of stimulus frequency $(F[2,82]=895, p<0.001)$ but no significant interaction

However, not all challenge doses of AMPH were effective. Striatal tussue from AMPH pretreated animals showed a greater elevation in DA release than tissue from control animals when challenged with $5 \mu \mathrm{M}$ AMPH for $5 \mathrm{~min}$ or $10 \mu \mathrm{M}$ for $2.5 \mathrm{~min}$, but not when challenged with lower doses (0.5 and $275 \mu \mathrm{M})$. In companson, Robinson \& Becker (11) reported sensitization-related changes in striatal DA release when $1 \mu \mathrm{M}$ of AMPH was infused continuously for $10 \mathrm{~mm}$. Similarly, using an incubation procedure, Kolta et al. (10) found that both $1 \mu \mathrm{M}$ and $10 \mu \mathrm{M}$ AMPH were effectuve when applied for $15 \mathrm{~min}$, although the $10 \mu \mathrm{M}$ challenge more clearly differentiated the AMPH pretreated and control groups than did the $1 \mu \mathrm{M}$ challenge. In one study, a much higher dose of AMPH ( $1 \mathrm{mM}$ ) was delivered as a brief pulse, which quickly washed out of the chamber, and this also resulted in a sensitization-related enhancement in strnatal DA release (12). Taken together, the avarlable evidence suggests that the ability of an in vitro AMPH challenge to reveal sensitzzation-related changes in striatal DA release is influenced by the duration and concentration of the AMPH challenge. The effects of AMPH pretreatment on AMPH-stumulated DA release may be seen under some experimental conditions, but not others

The effect of AMPH pretreatment on the Ca+t-dependent DA release evoked by either high $\mathrm{KCl}$ or electrical field stimulation reported here appears to be discrepant with a previous study from this laboratory, in which it was found that $\mathrm{KCl}$-evoked striatal DA release was not enhanced in sensituzed rats (11). The most probable explanation for this is an order effect. In the Robinson and Becker (11) study striatal tissue was always exposed first to AMPH, and then to $\mathrm{KCl}$. Therefore, AMPH may have depleted the amount of DA avallable for subsequent $\mathrm{KCl}$-stumulated DA release It is thought, for example, that AMPH displaces bound DA from storage pools (14), which would leave less DA available for subsequent release by $\mathrm{KCl}$. There was no such order effect in the present experiments, because the data are based only on the initial response to e1ther AMPH, $\mathrm{KCl}$ or electrical stumulation.

As mentioned in the introduction, the process thought to mediate AMPH-stumulated DA release (Ca++-independent, carrier-mediated exchange-diffusion) is very different than that thought to mediate DA release produced by depolanzation of axonal termunals (Ca++-dependent exocytosis). Therefore, the observation that sensitization is accompanied by an enhancement of not only AMPHstumulated DA release, but also of $\mathrm{KCl}$ and electrical stumulation-evoked DA release, has important implications for hypotheses regarding the neurobiological basis of the enhancement in DA release. Either the sensitization-related enhancement in DA release is due to more than one mechanism, for example, one responsible for the enhancement in AMPH-stumulated DA release and another for the enhancement in depolarization-induced DA release, or, a mechanism common to both AMPH and depolarization-induced DA release is involved.

There are many neuronal adaptations that could lead to increased DA release, but most have difficulty accountung for changes in both depolanzation-induced DA release and AMPH-stumulated DA release For example, it has been suggested that the sensitization-related enhancement in DA 
release and AMPH-induced behavior may be due to a subsensitivity of DA autoreceptors (35-37). But AMPH-stumulated DA release does not seem to be modulated by DA autoreceptors (38), and therefore, it is not clear how a change in DA autoreceptors could account for the sensitization-related enhancement in AMPH-stumulated DA release and AMPH-evoked behavior. Simularly, a role for $\mathrm{Ca}^{++}$in AMPH sensituzation is suggested by a report of increased stratal calmodulın levels in AMPH pretreated rats (39) But AMPH-stumulated DA release is not $\mathrm{Ca}+-$-dependent, and therefore, it is not obvious how changes in $\mathrm{Ca}++$ influx or a Ca++-binding protein could account for changes in AMPH-stimulated DA release and AMPH-elicited behavior A change in AMPH-stumulated DA release could be due to an alteration in the reuptake carner. But the $\mathrm{Ca}++$-dependent release produced by $\mathrm{KCl}$ is not affected by the presence of the DA reuptake blocker nomifensine, and this suggests that depolanzation-induced release occurs independently of the uptake mechanism (40). Therefore, changes in the uptake mechanism could mediate the enhancement in AMPH-stimulated release, but presumably not the effects of AMPH pretreatment on $\mathrm{Ca}^{++}$-dependent DA release

The idea that a common mechanusm mediates the enhancement in both AMPH-stımulated and depolarization-induced striatal DA release should be given serious consideration, not only because it is more parsimonious, but because it could also help explain the interchangeability of AMPH and stress in producing sensitization. Animals sensitized to AMPH exhibit enhanced behavioral and neurochemical responses to subsequent stress $(23,41,42)$, and prior stress enhances the behavioral and neurochemical responses to a subsequent AMPH challenge $(23,24,41,43-45)$.

How could a single change alter the releasability of DA to both AMPH and depolarization? It is not due to just an increase in the total amount of presynaptic DA, because AMPH pretreatment does not alter mesotelencephalic DA concentrations $(15,18,46-48,5$ for review). But it is important to consider that DA is probably located in at least 3 different compartments, or 'pools', and release occurs more readily from some pools than from others $(9,49-52)$. A free cytoplasmic pool is thought to contain newly synthesized DA, largely because tyrosine hydroxylase and dopadecarboxylase are not associated with synaptic vesicles (52) AMPH seems to release DA selectively from this pool. Metabolically older neurotransmitter is presumably bound within storage compartments, for protection from metabolism, until it is released by a $\mathrm{Ca}^{++}$-dependent release process. Bound pools of DA might correspond to vesicular stores, and there are probably two pools of bound DA; one that is readily releasable by the arnval of an action potentnal at the nerve termunal ('releasable bound $\mathrm{DA}^{\prime}$ ) and another that is not ('inactuve bound DA') The difference between these two bound pools may be that releasable bound DA is simply closer to the neuronal membrane than the inactive pool, and thus has greater access to release sites (50) A redistribution of DA among these pools, with no change in total DA, could lead to an increase in both AMPH and depolanzationinduced DA release in the following way

A transfer of DA from the inactive bound pool into the releasable bound pool would obviously result in more DA readily avallable for release upon depolanzation of the terminal. There would be no alteration in the size of the cytoplasmic pool in the absence of an AMPH challenge After AMPH is taken up into a DA terminal, however, it not only unduces DA release into the extracellular space by exchange-diffusion, but it also displaces bound DA into the cytoplasm $(9,14)$. Thus, if AMPH pretreatment enhanced the size of the releasable bound pool, for example, by a physical translocation of vesicles closer to release sites on the presynaptc membrane, then presumably they would also be closer to reuptake sites on the presynaptic membrane. AMPH that had just entered the cytoplasm would, therefore, have access to an augmented releasable bound pool and a greater opportunity to displace DA from this augmented releasable bound pool This would increase the amount of DA in the cytoplasmic pool, resultung in more DA being readily avallable for exchange-diffusion as AMPH entered the cell. In conclusion, it is suggested that a single change - an increase in the size of the releasable bound pool of DA - could result in an enhancement of both AMPH and depolarizationinduced DA release

This hypothesis is speculative, and further research is required to determine the neurobiological basis of the enhancement in DA release produced by AMPH pretreatment Nevertheless, the present study suggests that exploration of presynaptuc mechanisms that concomitantly regulate both uptake carrier-mediated chemical release and impulse-related $\mathrm{Ca}^{++-d e p e n d e n t ~ r e l e a s e ~ m a y ~ p r o v i d e ~ a ~}$ 
promising strategy for increasing our understanding of the biological basis of behavioral sensitzation

In summary, it was shown that the behavioral sensitization produced by repeated intermittent injections of AMPH is accompaned by a persistent enhancement in AMPH-stumulated endogenous striatal DA release, and in Ca++-dependent DA release evoked by high $\mathrm{KCl}$ or electrical stimulation in vitro. These results support the hypothesis that an enhancement in stratal DA release may be at least partly responsible for the behavioral sensitization seen in AMPH-pretreated animals $(5,11)$, and perhaps even the hypersensituvity to the psychotogenic effects of AMPH seen in former AMPH addicts (53-55). Of course, this does not exclude the possibility that changes in other neural systems are also involved (eg. 5, 23, 41, 45, 56). The observation that sensitization-related changes in DA release are not unique to AMPH-stimulated DA release is also consistent with the hypothesis that behavioral sensitization is not unique to the psychopharmacology of AMPH (56).

\section{Acknowledgements}

This research was submitted by Dr. Castañeda in partıl fulfillment of requirements for a Ph.D. in Psychology (Biopsychology) at the University of Michigan, Ann Arbor. It was supported by grants from the NIH (MH37277) and Scottish Rite Schizophrenia Research Program. Dr. Castañeda was supported by a Rackham Minority Mert Fellowship from The University of Michigan, and Drs. Becker and Robınson by NIH Research Career Development Awards (NS01056 and NS00844). Dr. Castañeda is presently an Alberta Heritage Foundation Postdoctoral Fellow in the Department of Psychology, University of Lethbridge, Lethbridge, Alberta, Canada.

\section{References}

1. P.H. CONNELL, Amphetamine Psychosis, Chapman and Hull, London (1958).

2. E.H. ELLINWOOD, A. SUDILOVSKY and L.M NELSON, Am J Psychiatry, 130, 10881092 (1973)

3. D. S. JANOWSKY and C. RISCH, Psychopharmacology, 65, 73-77 (1979).

4. D.S. SEGAL and D.S. JANOWSKY, Psychopharmacology: A Generation of Progress, M.A. Lipton, A. DiMascio and K.F. Killam (Eds.), pp. 1113-1123, Raven, NY (1978).

5. T.E. ROBINSON and J.B. BECKER, Brain Res Rev , 11, 157-198 (1986).

6. D.S. SEGAL, M.A. GEYER and M.A. SCHUCKIT, Essays in Neurochemistry and Neuropharmacology, Vol 5, M B.H. Youdim, W. Lovenberg, D.F. Sharman and J.R. Lagnado (Eds.), pp. 95-129, John Wley and Sons, London (1981).

7. H.C. FIBIGER and A.G. PHILLIPS, Handbook of Physiology, Vol. 4, pp. 647-675, Amencan Physiological Society, Bethesda, MD (1986).

8. S.D. IVERSEN Handbook of Psychopharmacology, Vol 8, L.L. Iversen, S.D. Iversen and S.H. Snyder (Eds.), pp. 333-384, Plenum, NY (1977).

9. R. KUCZENSKI, Sttmulants Neurochemical, Behavioral and Clinical Perspectives, I. Creese (Ed), pp. 31-61, Raven, NY (1983).

10 M.G KOLTA, P. SHREVE, V. DE SOUZA and N.J URETSKY, Neuropharmacology, 24, 823-829 (1985).

11. T.E. ROBINSON and J.B. BECKER, Eur. J. Pharmacol., 85, 253-254 (1982).

12. T.E. ROBINSON, J.B. BECKER and S.K. PRESTY, Brain Res., 253, 231-241 (1982).

13. J. PERIS and N.R. ZAHNISER, Pharmacol Biochem Behav, 27, 533-535 (1987).

14. J.F. FISCHER and A K. CHO, J Pharmacol Exp Ther, 208, 203-209 (1979).

15 D M. CAMP and T.E. ROBINSON, in press, Behav. Brain Res (1987a).

16. T.E. ROBINSON, Psychopharmacology, 84, 466-475 (1984)

17. J.B. BECKER and V.D. RAMIREZ, Neuroendocrinology, 31, 18-25 (1980).

18. D.M. CAMP and T E. ROBINSON, in press, Behav. Brain Res. (1987b)

19. A.J. MACLENNAN and S.F. MAIER, Sclence, 219, 1091-1093 (1983).

20. G.V. REBEC and D.S. SEGAL, Pharmacol Biochem Behav, 13, 793-797 (1980) 
21. T.G. HEFFNER, J.A. HARTMAN and L.S. SEIDEN, Pharmacol. Blochem Behav., 13, 453$456(1980)$.

22. J.B. BECKER, E. CASTAÑEDA, T.E. ROBINSON and M E. BEER, J. Neuroscl Meth., $I I$, 19-28 (1984).

23. T.E. ROBINSON, J.B. BECKER, E.A. YOUNG, H. AKIL and E. CASTAÑEDA, Neuropharmacology, 26, 679-691 (1987).

24. R.A. WILCOX, T.E. ROBINSON and J.B. BECKER, Eur. J. Pharmacol., 125, 375-376 (1986).

25. H.F. BRADFORD, Methods of Neurochemistry, R. Fried (Ed.), pp. 155-202, Marcel Dekker, NY (1972).

26. H. MCILWAIN and R. RODNIGHT, Practical Neurochemistry, pp. 155-160, Little, Brown, and Co., Boston (1962).

27. H. MTYAMOTO and M. KASAI, J. Gen. Physiol., 62, 773-786 (1973).

28. F. ORREGO, Neuroscience, 4, 1037-1057 (1979)

29. J. ACEVES and A.C. CUELLO, Neuroscience, 6, 2069-2075 (1981)

30. D.S. SEGAL and A J. MANDELL, Pharmacol Blochem Behav , 2, 249-255 (1974)

31. A.J EICHLER, S.M. ANTELMAN and C.A BLACK, Psychopharmacology, 68, 287-290 (1980).

32. H.L. KLAWANS and D I. MARGOLIN, Arch Gen. Psychlatry, 32, 725-732 (1975).

33. L. MAGOS, Eur $J$ Pharmacol , 6, 200-201 (1969)

34. N ROWLAND, S M. ANTELMAN and D. KOCAN, Appettte, 2, 51-66 (1981).

35. S.M. ANTELMAN and L A. CHIODO, Biol Psychatry, 16, 717-727 (1981).

36 P. MULLER and P. SEEMAN, Eur $J$ Pharmacol, 55, 149-157 (1979).

37. G.V. REBEC, Monogr. Neural Sci, 10, 207-223 (1984)

38. L.A. KAMAL, S. ARBILLA and S.Z. LANGER, $J$ Pharmacol Exp Ther , 216, 592-598 (1981)

39. J.M ROBERTS-LEWIS, M J WELSH and M E. GNEGY, Brain Res , 384, 383-386 (1986).

40 M RAITERI, F. CERRITO, A.M CERVONI and T. LEVI, J Pharmacol. Exp Ther, 208, 195-202 (1979)

41. S M. ANTELMAN and A J EICHLER, Catecholamines Basic and Clinical Frontiers, Vol 2, E Usdin, I J Kopın and J. Barchas (Eds.), pp 1759-1761, Pergamon, NY (1979).

42. S.M ANTELMAN, A.J. EICHLER, C.A. BLACK and D KOCAN, Sclence, 207, 329-331 (1980).

43 J.-P. HERMAN, L STINUS and M. LE MOAL, Psychopharmacology, 84, 431-435 (1984).

44 T E ROBINSON, A.L ANGUS and J B. BECKER, Life SCl, 37, 1039-1042 (1985).

45 T.E ROBINSON, J B. BECKER, C J. MOORE, E. CASTAÑEDA and G MITTLEMAN, Brain Res , 343, 374-377 (1985)

46 R KUCZENSKI and N J LEITH, Pharmacol Btochem Behav, 15, 405-413 (1981)

47 T. NISHIKAWA, N. MATAGA, M TAKASHIMA and M TORU, Eur $J$ Pharmacol, 88, 195-203 (1983).

48 T E. ROBINSON and D.M. CAMP, Pharmacol Blochem Behav , 26, 821-827 (1987).

49 J. GLOWINSKI, Handbook of Psychopharmacology, Vol 3, L L. Iversen, S D Iversen and S.H. Snyder (Eds ), pp. 139-168, Plenum, NY (1975).

50. J.B JUSTICE, L C NICOLAYSEN and A.C MICHAEL, $J$ Neuroscı Meth, 22, 239-252 (1988)

51. B.A. MCMLLEN, D C. GERMAN and P A SHORE, Biochem Pharmacol, 29, 3045-3050 (1980)

52 A H MULDER, Chemical Transmission in the Brain, Progress in Brain Research, Vol 55, R.M Buijs, P. Pévet and D F Swaab (Eds.), pp 135-156, Elsevier Biomedical, Amsterdam (1982)

53 B M. ANGRIST, J ROBERTSON and S GERSHON, Psychopharmacology, 67, 31-38 (1983)

54 M. SATO, Psychopharmacol Bull , 22, 751-756 (1986)

55. M. SATO, C.-C CHEN, K. AKIYAMA and S OTSUKI, Bıol Psychlatry, 18, 429-440 (1983).

56 S.M. ANTELMAN and L A CHIODO, Stmulants Neurochemical, Behavioral and Clinical Perspectives, I Creese (Ed.), pp 269-299, Raven, NY (1983) 